\title{
The Influence of COSO Preventative Control Operations on Revenue Mobilization in Ugandan Schools
}

\author{
Liz Nantunda ${ }^{*}{ }^{*}$, Livingstone Ddungu ${ }^{2}$, Jonny R. Munby ${ }^{1}$, Catherine McCauley-Smith ${ }^{1}$ \\ ${ }^{1}$ Teesside University Business School, Teesside University, Middlesbrough, UK \\ ${ }^{2}$ College of Education and External Studies, Makerere University, Kampala, Uganda \\ Email: ${ }^{*}$ lizleatitia@gmail.com
}

How to cite this paper: Nantunda, L., Ddungu, L., Munby, J. R., \& McCauley-Smith, C. (2020). The Influence of COSO Preventative Control Operations on Revenue Mobilization in Ugandan Schools. Open Journal of Business and Management, 8, 1587-1608. https://doi.org/10.4236/ojbm.2020.84101

Received: June 17, 2020

Accepted: July 14, 2020

Published: July 17, 2020

Copyright $\odot 2020$ by author(s) and Scientific Research Publishing Inc. This work is licensed under the Creative Commons Attribution International License (CC BY 4.0).

http://creativecommons.org/licenses/by/4.0/

\begin{abstract}
This article provides informative insights into the failure of many Stakeholders to attain the desired Ugandan private secondary schools, to realise their desired revenue and how that failure has caused critical investment concerns due to negative impacts on expected returns on investment. Therefore, the study drew upon that to explore whether preventive control practices within the COSO control activities contribute to this failure. The study used an interpretivism approach and was guided by conceptual COSO control activities component model. Data was collected using skype interview and thematic narrative technique was used for analysis. 16 internal stakeholders as Boards of Governors, headteachers, deputy headteachers, accountants and auditors were purposively selected from four private secondary schools located in central Uganda. Results indicate that control activities within the guidelines, segregated duties and IT environment in private schools' financial management are ensured in the mobilization of desired revenue. However, efficiency, reliance and compliance differ in a positive or negative influence. Therefore, this study is relevant for internal stakeholders in private school businesses to ensure designing effective COSO control activities policies that influence preventive financial controls for achieving desired revenue to avoid bankruptcy.
\end{abstract}

\section{Keywords}

Guidelines, Segregated Duties, IT Environment, Realising Revenue, Private Schools

\section{Introduction}

In this global economy, investors focus on obtaining the best outcomes of the 
business such as planned revenue (Becker, 2015). However, it remains a challenge due to the quality of financial control practices used within the internal and external financial management process (PWC, 2013). Hopkin (2018) refers to preventive controls as risk control practices that limit undesirable outcomes and adds that this is applicable with the help of embedding practices within the activities involved in running the business and company guidelines. COSO alternatively, defines the controls as mitigations of identified risks that aid the achievement of organisational objectives (Schandl \& Foster, 2019). When these controls are implemented, these risks can be identified, controlled and avoided (Kaplan \& Mikes, 2014). Therefore, it is uncertain whether preventive controls used by investors in secondary schools to realise planned revenue as a performance indicator in relation to school fees, have any impact on sustained realization of planned revenue. COSO (2004) and Janvrin et al. (2012) mentioned that internal controls are a contributing factor in quality service provision in health sectors. Such internal controls included efficient utilisation of resources, such as segregation of duties and employees' efficient use to generate profits (Gordon \& Kalenzi, 2019). Building on these empirical studies, it needs to be clarified whether it is the case for private school's financial administration in the mobilization of revenue is being influenced by the COSO factors to successfully sustain private schools in business. Bauer, Bucaro and Estep (2019) further emphasised that managers need to consider quality internal controls when implementing organisation standards to minimise risks like misstatements and other errors in financial material reporting. Therefore, the paper highlights the influence of COSO preventative control activities used in the revenue mobilisation of private secondary schools in Uganda.

There has been a rapid increase in the number of private secondary schools in Uganda with a total number of 1033 as government secondary schools, compared to 1785 private secondary schools (Crawfurd, 2017). This implies that the number of private secondary schools is increasing in the Ugandan market. This has been driven by the growing population of enrolment size, and affordable costs that have been encouraged by the improving government policies for wealth creation to minimise unemployment and poverty (Jacob, Holsinger, \& Mugimu 2008). This continuous investment in secondary schools has encouraged improved access to education for Ugandan citizens with prevailing challenges on the investor's side as controls of financial risk in attaining planned revenue (Jacob, Holsinger, \& Mugimu, 2008). Other scholars, Tumwebaze et al. (2018) point out that internal auditing is a significant factor in management of accountability risks in Ugandan businesses; however when overlooked, then risks in accountability are unavoidable. Nevertheless, the majority tend to have a keen interest in realising the revenue planned from their investments for sustainability purposes (Cuaresma \& Raggl, 2016). Specifically, Crawfurd (2017) indicates that most of the established in Uganda schools fail to generate the planned revenue, which is a significant managerial risk that leads to bankruptcy. Evidence 
for this failure is reflected in the four private secondary schools in Uganda used in this article as case study. The analysis of their financial reports indicates that between the years 2013 to 2017 there was consistent failure in raising revenue with unstable variances between expected and actual revenue realised in US dollars ranging from $\$ 94,210$ to $\$ 230,724$, which made it risky to support other school investments that would generate more money (L. Nankumba, personal communication, July 22, 2017). Ssekiziyivu (2013) analysed that schools' weak internal administration and macroeconomic factors such as inflation, high interest and tax rates, were contributory factors too. Yet, Vinnari and Skærbæk (2014) focus on uncertainties such as risks in detective internal controls in Nantunda and Ddungu (2018) on school monitoring financial activities to deliver quality services. Therefore, the focus of this article is to ascertain whether these measures, with the aid of the COSO control activities, are practised within the preventive controls in Ugandan private schools and whether they explain the revenue collected. This will be guided by an objective to explore the internal stakeholders' views on preventive controls used, and their influence on the mobilized revenue in multiple case study of four private secondary schools in Uganda.

\section{Literature Review}

\subsection{Preventive Control Guidelines in Risk Management}

According to Commonwealth Secretariat (2005), scrutiny indicated that the COSO control activities companies design procedures are prescribed in which they manage their internal control processes that enable a business in realising its financial goals. Burns et al. (2014) credit the body to have streamlined standards of formulating reliable risk management strategies in any business. It is further emphasised that these internal controls need to be synchronised in four aspects in operation processes which include; effective, efficient, reliable, and compliant manner (Financial Reporting Council, 2005). Drawing upon this, according to Commonwealth Secretariat (2005) and PWC (2013) preventive financial control was an attribution factor that was embedded in the COSO control activities that minimised on risks, if actioned in reliable, predictive and analytical manner. In earlier studies, Löfsten (1999) pointed out appropriate management as a preventive control factor, encouraged effective and efficient achievement of organisation targets. Likewise, Mpolokeng (2011) mentioned setting revenue mobilization guidelines as another vital preventive control strategy as an effective measure for avoiding unacceptable practices of raising funds. However, he added that this form of control is unreliable since it discouraged new proprietors, especially in school businesses when inventing sources of raising revenue in South African schools. Rather, it depends on what is complying with the standard of COSO control activities which hinders raising planned revenue (Mpolokeng, 2011; Schandl \& Forster, 2019). On the other hand, Tumwebaze et al. (2018) analysed that businesses in Uganda are continuously struggling due to poor implemented methods used in accountability compliance activities by the 
Ugandan government, intended to limit risk in internal auditing activities within cooperating businesses in Uganda in general. These scholarly views were scrutinised in the USA, South African and Indian context, although those in the Ugandan context, were unspecific of which preventive control featured in private schools. Therefore, this study focused on establishing the strict sense of reliance, compliance, and effectiveness of perceived operating preventive financial control within the procedures, duties and IT environment used in realising or discouraging revenue as planned in the Ugandan private schools' context.

\subsection{Preventive Controls in Segregation of Duties in Risk Management}

Within organisations, segregation of duties was credited as an effective and efficient risk control barrier that is physical, in ensuring accountability through reporting, actual process and complying to roles assigned (Schandl \& Forster, 2019). These two add that when mobilising revenue, this segregation involves allocation of specific responsibilities to different individuals involved in the process of raising planned finances. It is an effective control of operational activities within the organisation which reports revenue (Rubino \& Vitolla, 2014). Tarantino (2010) mentioned that these duties may be issuing of deposit, receipting of revenue, accounting, safekeeping, reconciliation and reporting, were reliable when assigned to particular individuals as efficient and effective practises in managing risks. Alternatively, Aase (2009) pointed out that preventive financial control practices used in secondary schools were setting financial regulations, standards, procedures, and segregating financial duties, this streamline authorization and verification of financial mobilization, and expenditure as effective and efficient risk management measures. Scholars Aase (2009) and Oche (2009) noted that most of these are neglected by headteachers even after acknowledging that applying the control would have enhanced planned revenue or even do without them in some cases. Gathii et al. (2014) added that segregating of duties is a reliable measure of minimising inaccuracy risk such as errors and fraud. Alternatively, Nantunda and Ddungu (2018) conducted a study in Ugandan private school indicating that detective control practises in revenue achievement had a significant impact on effective education services. Bakalikwira et al. (2017) supplemented that efficient accountability in the healthy sectors in Uganda is still an ongoing challenge. These studies although they were examined in Nigeria, USA, using quantitative techniques or in a different country context, besides those analysed in Uganda were conducted in health sector, those in schools considered other controls instead of preventive financial control. Therefore, this study specifically analysed the perceived preventive controls within the segregation of duties that led to or discouraged realisation of desired control and were designed within the COSO control activities components in private schools' context in Uganda.

\subsection{COSO Control Activities and Preventive Financial Control}

The COSO model is a useful framework for implementing procedures to be used 
within internal control processes since 1992 (PWC, 2013). Rezaee (1995) analysed that this model allows organisations to prioritize the practice in internal controls. Additionally, internal control systems as per the COSO framework have been globally developed as effective compliable measure to ascertain quality financial reporting (Rubino \& Vitolla, 2014). Implying, COSO guides the quality process in which implemented procedures at an organisational level are determined, to ensure efficiency and effectiveness in operations; reliability in reporting, and compliance with standard laws and regulations (Rezaee, 1995; Rubino \& Vitolla, 2014). According to some, this model is effective in paving the way for a business to develop a comprehensive structure of internal controls as verification, approval, segregation of duties (PWC, 2013). A report from Professional Accountants in Business (PAIB, 2006), clearly stipulates that prevention of risks through managerial planning is an effective way of containing the impact of the outcome in businesses, in this case preventive control practices used in realising desired revenue in schools. Components within the model; control environment, risk assessment, control activities, activities monitoring, and considered effective, as shown in Figure 1.

However, the research focused on the "Control activities" component of COSO model as paramount, as selecting and developing control activities, selecting and developing general control over technology, and deploying through policies and procedures (Burns et al., 2014; PWC, 2013). According to Janvrin et al. (2012), policy and procedure are key strategies to ensure the achievement of the companies' planned revenue. This system of control practice, when neglected, results in uncertainties in obtaining desired revenue to efficiently meet the school's goals to provide adequate services (Loeb, Bryk, \& Hanushek, 2008). Aase (2009) concluded that attaining higher achievement in performance is more likely when risks are predictive rather than prescriptive which is in line with Turnbull internal control. Additionally, the COSO framework is still inefficient in addressing various risks incurred in the complex IT environment (Rubino \& Vitolla, 2014). These views led the study to establish the validity of the Ugandan private school stakeholders' operation in technology, procedures and guidelines to prevent the risks in order to realise their revenue from fees mobilization. Therefore, a conceptual framework was used to understand this using the adopted model as in Figure 2.

The conceptual model was based on assumption to examine the use of COSO control activities in the model that was embedded in the perceived preventive financial controls of school when realising the mobilization of desired revenue. Descriptions of COSO control activities were adopted from Burns et al. (2014) and Financial Reporting Council (2005) who assumed the COSO control activities component when addressed through segregation of incompatible duties; mitigating risk associated with incompatible duties that may be incapable of being segregated; and those related to IT environment. There is an assumption that once designed within preventive financial control guidelines, procedures and physical barriers described in studies by (Aase, 2009; Commonwealth Secretariat, 


\begin{tabular}{|c|c|c|c|c|}
\hline \multicolumn{5}{|c|}{ Control Components and Summarized Principles } \\
\hline $\begin{array}{c}\text { Control } \\
\text { Environment }\end{array}$ & $\begin{array}{l}\text { Risk } \\
\text { Assessment }\end{array}$ & $\begin{array}{c}\text { Control } \\
\text { Activities }\end{array}$ & $\begin{array}{l}\text { Information and } \\
\text { Communication }\end{array}$ & $\begin{array}{l}\text { Monlitoring } \\
\text { Activities }\end{array}$ \\
\hline $\begin{array}{l}\text { 1. Demonstrates } \\
\text { commitment } \\
\text { to integrity and } \\
\text { ethical values. } \\
\text { 2. Exercises } \\
\text { oversight } \\
\text { responsibility } \\
\text { 3. Establishes } \\
\text { structure, } \\
\text { authority, and } \\
\text { responsiblity. } \\
\text { 4. Demonstrates } \\
\text { commitment to } \\
\text { competence. } \\
\text { 5. Enforces } \\
\text { accountabiliy. }\end{array}$ & $\begin{array}{l}\text { 6. Specifies } \\
\text { suitable } \\
\text { objectives. } \\
\text { 7. Identifies and } \\
\text { analyzes risk. } \\
\text { 8. Assesses fraud } \\
\text { risk. } \\
\text { 9. Identifies } \\
\text { and analyzes } \\
\text { signficant } \\
\text { change. }\end{array}$ & $\begin{array}{l}\text { 10. Selects and } \\
\text { develops } \\
\text { control } \\
\text { activities. } \\
\text { 11. Selects and } \\
\text { develops } \\
\text { general } \\
\text { controls over } \\
\text { technology. } \\
\text { 12. Deploys } \\
\text { through } \\
\text { policies and } \\
\text { procedures }\end{array}$ & $\begin{array}{l}\text { 13. Uses relevant, } \\
\text { quality } \\
\text { information. } \\
\text { 14. Communicates } \\
\text { internally. } \\
\text { 15. Communicates } \\
\text { externally. }\end{array}$ & $\begin{array}{l}\text { 16. Conducts } \\
\text { ongoing and/ } \\
\text { or separate } \\
\text { evaluations. } \\
\text { 17. Evaluates and } \\
\text { communicates } \\
\text { deficiencies. }\end{array}$ \\
\hline
\end{tabular}

Figure 1. Components of the COSO model. Source: "Heads Up-Challenges and leading practices related to implementing COSO's: Internal Control-Integrated Framework”, by Burns, Deloitte, Herrygers, and Deloitte \& Touche LLP, 2014

(https://www.iasplus.com/en/publications/us/heads-up/2014/coso). Copyright 2014 by Deloitte LLP.

\begin{tabular}{|l}
\hline COSO control activities (Burns et al., 2014; \\
Financial Reporting Council, 2005) \\
- Controls that define and address \\
the segregation of incompatible \\
duties. \\
Controls that mitigate the risk \\
associated with incompatible \\
duties that may be incapable of \\
being segregated. \\
Controls related to IT \\
environment
\end{tabular}

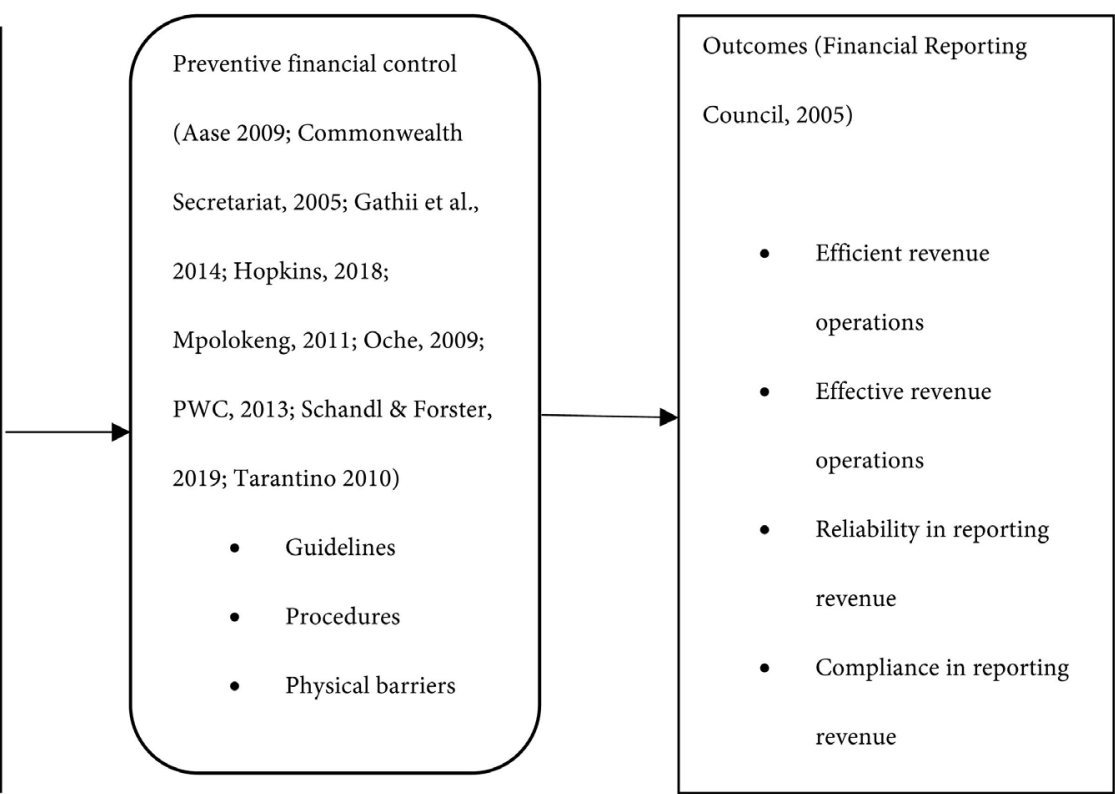

Figure 2. The conceptual frame of COSO control activities in relation of school mobilization revenue. Source: Authors (2020). Based on Burns et al., 2014 and Financial Reporting Council, 2005, operational definition of preventive financial control, and reviewed literature.

2005; Gathii et al., 2014; Mpolokeng, 2011; Oche, 2009; PWC, 2013; Schandl \& Forster, 2019; Tarantino, 2010) such as guidelines, procedures, segregation of duties and technology used in issuing of deposit, receipting of revenue, accounting, safekeeping, reconciliation, reporting, streamline authorization and verification. They are assumed to result in business efficiency, effectiveness, reliance, and compliance when mobilising revenue of business, in this case private 
schools and the reverse was true as in (Financial Reporting Council, 2005).

\section{Research Methods}

\subsection{Research Design, Population and Sample}

A qualitative Interpretivism paradigm approach was used based on a case study design of four secondary schools. Graneheim and Lundman (2004) argue that this approach enables data collected to be interpreted using individual opinions about a subject matter. Bhatta (2018) added that with case study design, it is possible to extract an in-depth understanding of what impact preventive control practices had on the planned revenue in schools. The participants included two board members, four headteachers, two deputy headteachers, six school accountants, and two auditors, totalling to a purposive sample size of 16 respondents from private secondary schools. This size was sufficient as with a saturation point which was reached, the respondents had no new information arising (Dam \& Volman, 2001). Board members were selected because, by virtue of their roles, they authorise and make policies used in financial guidelines used, which are embedded within the school preventive financial controls. Auditors and accountants were included to provide detailed information about the reliability, reporting, and compliance of the preventive controls to influence the revenue planned by the schools.

\subsection{Skype Interviews and Thematic Analysis}

Skype Interviews were conducted. This research was guided by interview guide instruments and was conducted face to face online using the Skype platform. This enabled participation from directors, deputy headteachers, headteachers, accountants, and auditors to explain in an open-ended manner about the asked topic subjects about financial guidelines, duties, and authorising procedures that influenced the mobilization of revenue. Interview guides containing set from topic areas such as; financial mobilization guidelines, regulations for authorization of financial spending, segregation of duties, and the financial reporting guidelines in the schools. Findings were reported using a thematic analysis technique the scholar's reviewed topics and stakeholders' views about the perceived influence of preventive control practices on the revenue collected in schools (Baxter \& Jack, 2010; Clandinin et al., 2007; Clarke \& Braun, 2016). According to Kendall and Kendall (2012), the views were constructed to make sense in this study through, investigating what could be seen, heard and felt in the process of collecting revenue. Meaning, that regulations are prescribed through recording in documents thus can be seen within the authorising duties, financial guidelines designed to support the duties and then the IT environment used to report the activities. Also, these practises are felt through authorisation prescribed verbally, and in practise and can be recognised, and finally can be felt through the process of carrying out the activities (McCauley-Smith et al., 2013). Themes were narrated in a manner which generated codes from views related to topics of preven- 
tive control and their impact on revenue indicator for quality education (Baxter \& Jack, 2010). Later, this enabled the scholar to make sense of the meaning from the views and constructed themes to address the article objective (Clarke \& Braun, 2016; Rea, 2008). Using the thematic analysis, it is an appropriate method to link these participants' views to the study topics on a conceptual occurrence from similar codes which maintains the consistence of the comparison between the views and the topics (Alhojailan, 2012). Therefore, the preventive financial control guidelines were interpreted into COSO control components of efficient, effectiveness, reliability and compliant, positive and negative results when realising school revenue according to schools' internal financial managers' experiences.

\subsection{Validity and Reliability}

The study interviews asked questions from internal top school stakeholders's in schools on financial preventive control area who were the actors and participants in the financial process of school activities of the schools (Alhojailan, 2012). Piloted interviews of the study were used with different schools suing anonymous participants from school finance department, this was used to confirm the reliability of the structured interview guide. During the interview, notes were taken to which ensured reliable patterns of the study topics and opinions obtained without altering the information (Middendorf \& Macan, 2002). Finally, the themes were cross check with an independent professional with fewer differences from those generated (Alhojailan, 2012). This ensured the study was valid and reliable to address the research objective.

\section{Results}

Two thematic themes featured in the study results, which were explained using preventive financial control of guidelines and segregation of duties, and their influence on private school risk management in the schools as summarized in visual Matrix 1.

\subsection{Guideline and Procedures Implemented in Schools' Revenue Mobilization}

The results from the study indicated that private school internal stakeholders had preventive financial guidelines used in revenue mobilization. These controls were procedures used in holding meetings through organised school board financial committees, holding meetings with accountants and consulting accounting professionals. Policies were designed through these channels in order to structure effective budgeting, authorisation of bank slips, recording receipts, reconciliation suing bank statements which were reliable and enforced when bookkeeping and raising the money. The following interview questions guided the scrutiny in the schools' control financial guidelines implemented in mobilization of revenue as follows: 


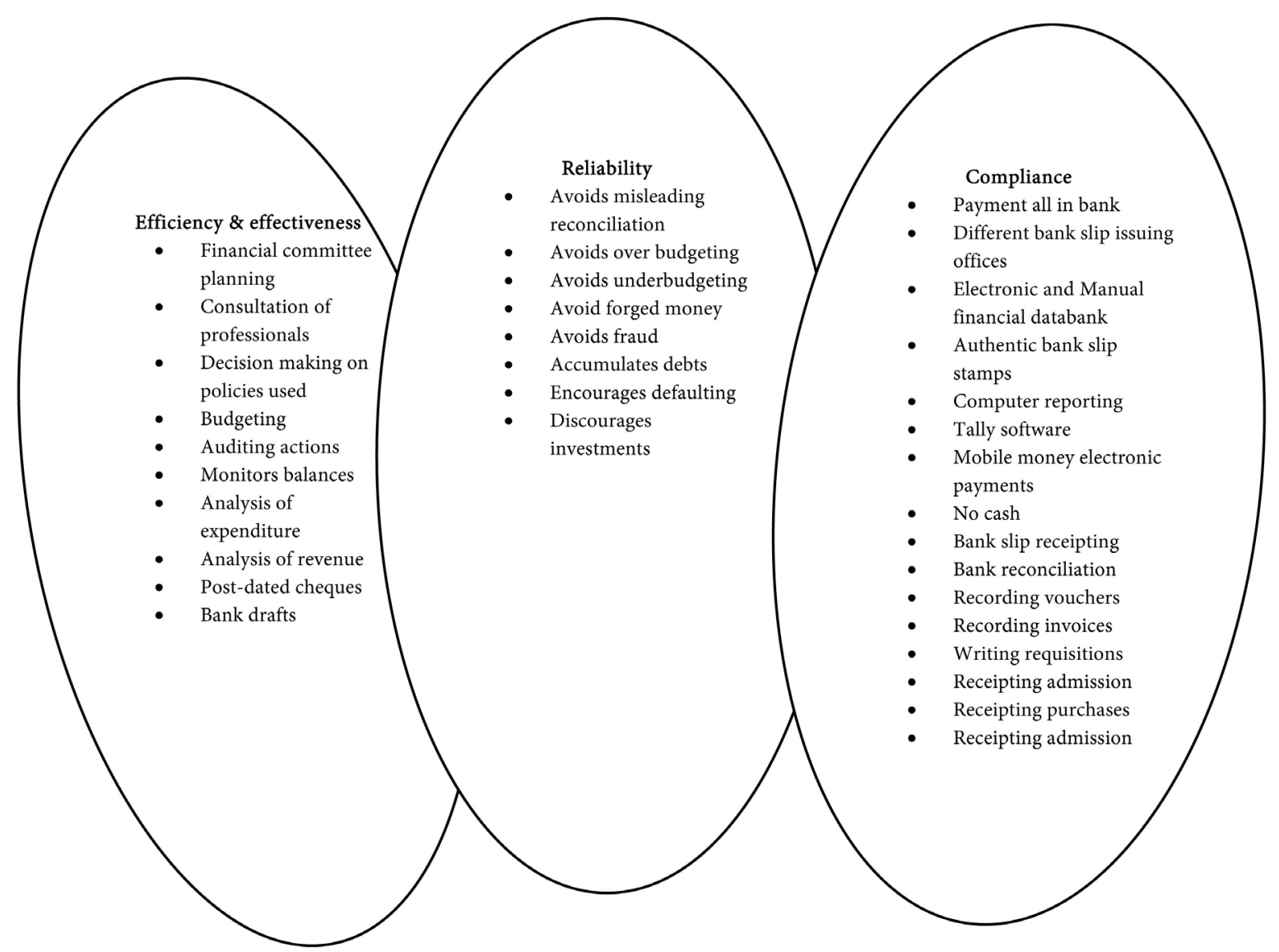

Matrix 1. Summarised codes embedded in preventive financial control used in private schools' revenue mobilization. Source: Authors (2020).

1) Using relevant example(s) mention the financial formulated guidelines followed to mobilize funds needed to run the school.

2) Could you describe how effective the guidelines mentioned in (a) affect or influence the investment performance of the school?

3) As an individual describe how the financial guidelines applied to guide mobilization of funds influence the investment activities of the school.

When asked question one (1) this is the comment of one of the board members Violet:

"The Board of Governors and Board of Directors meet two weeks before the beginning of every school term to agree on and pass the policy proposed by the School Finance Committee on how budgeted revenue should be raised. Usually, the policy indicates the proposed revenue sources, how much money is expected from each source, and guidelines for its collection"

Indeed, the guidelines were in existence because another board member Chocolate when asked echoed this:

“Our schools' Finance Committee proposes a revenue policy. Before the Board meets to consider and pass the proposed policy, it hires a profession- 
al consultant to scrutinise the policy and prepare guidelines that should apply to all our schools as far as mobilising the proposed amount of revenue is concerned. ...consultant submits the guidelines, the Board of Governors and Board of Directors convene to discuss and pass them into a policy for guiding how the schools' financial resources should be raised while minimising risks such as fraud through issuing unauthorised bank slips, un-receipting, unsafe keeping of collected revenue, deceitful bank reconciliations, and the like."

There is empirical evidence from Violet and Chocolate that PWC (2013) control activities are used in use implementation of school's financial guidelines confirmatory to the description by Burns et al. (2014) as a compliance measure to structure rules that aid in controlling risks of revenue mobilization in schools. Hopkin (2018) and Păunescu (2020) supplement that organisations are accepted to design their own policies and procedures in order to address the risks identified by management. When as the effectiveness and efficiency and its influence on the mobilised revenue of the used guides. One of the respondents replied:

"....all school fees have to be paid in the bank using a bank slip issued by the school accountant. No cash is supposed to be received by any school accountant. This guideline is intended to avoid the temptation of swindling cash. ...each student has to present a fully paid-up bank-stamped slip to the accountant before being accepted back into the school. The other guideline is that the amount of fees each student should pay should be determined after determining each school's expenditure budget. ...to avoid under- or over-budgeting".

Drawing upon this view, headteacher Silver and Lemon evidence that they are guidelines implemented by superiors such as directors and chair board members, which enforce control of complexity in duties of budgeting for school accountants. This is intended to avoid over budgeting and over estimation which is an effective and efficient activity in school raising and spending of revenue in the school. These view support studies that induced positive outcomes from segregation of duties (Aase, 2009; Commonwealth Secretariat, 2005; Gathii et al., 2014; Mpolokeng, 2011; Oche, 2009; PWC, 2013; Schandl \& Forster, 2019; Tarantino, 2010). In conclusion, there are preventive financial control guidelines designed in private schools when collecting fees in association to the COSO control segregated duties and regulations. The school not only practices implementing procedures and guidelines, they enforced this through the processes used in mobilising the revenue as explained in the next section.

\subsection{Segregation of Duties Control Activities Influence on School Revenue Mobilization}

Results indicated that there were control activities used in the private schools through segregated duties carried out by accountants and internal auditors. 
These results indicated that there are positive and negative implemented and practiced controls used in private schools to minimising risks in mobilising revenue, by asking questions related to authorisations which are listed as follows;

1) Using an example(s) explain the regulations that are followed when authorizing the spending of money on investments undertaken at the school.

2) Using an example(s) in (a) explain the effect of the regulations on the investments undertaken in the school.

3) Using an example(s) in (a) describe challenges in the present regulations and how best they can be improved.

The results presented evidence that there was a reporting process which was mandatory to follow within the duties carried out. One of a school Headteachers Silver had this to say:

"First..., we are not allowed to receive school fees in cash. We are required to issue bank slips and receive them back when they are fully paid up and confirmed by authentic bank stamps. The office that issues the bank slips is not supposed to be the same office to receive paid up bank slips. This is intended to minimise fraud that might arise from unfaithful staff and fake money from parents".

This control activity was reliable in such that it avoided fraud and misleading information of financial reporting among staff member. This argument overruled the fact by Aase (2009) whose study indicated that head teacher overlooked the authorising guidelines which result in poor financial reporting. However, Ugandan private schools' headteacher enforced this in fees mobilization by enforcing use of school bank slips on depositing revenue, as well as, encouraging recording receipts as an efficient measure of authorising activities. These views were echoed by six other respondents. One who was school senior accountant Green, who indicated that control practise as segregating duties accordingly. Reporting that the personnel issuing and receiving bank slips were not supposed to be the same people carrying out bank reconciliations, and that all students were supposed to present fully paid up bank slips before being allowed back into the school. This measure ensures that all the revenue needed to fund school programmes was collected in time. This result credited Rubino and Vitolla (2014) suggesting having effective preventive control encourage positive outcome, as it was in the case of this school. Other guidelines were highlighted by various accountants, starting with accountant Black who had this to say;

“....another guideline requires us to use receipt books to record all the money received in cash such as 'admission fees' then, accountant Purple pointed out receipting 'purchased renewal of school uniform fees'. All the cash should be received by the Accounts Office and by a particular individual to minimise double entry, Also, accountant Pink and Accountant Yellow reported that the original receipt was to be issued to the admitted student. The school had to retain the duplicate copy whose number and paid 
amount later entered in the school's financial databank for record and auditing purposes. These guidelines require all the money received in cash to be deposited on the school's bank account."

Results featured that enforcing segregation guidelines of recording financial information's also had a positive impact on the realisation of desired revenue. He pointed out that different offices were responsible for receipting admission money, purchase of scholar items. This is the avoided duplication which could cause misleading auditing information which was confirmatory in (PWC, 2013; Tarantino, 2010).

On the contrary they were featured guidelines with positive and negative influence on collected revenue in private schools. On the positive side, accountant Blue explained this through the accrual-based system accounting control guidelines. She reports that this was introduced to monitor students' ledger accounts that had not fully paid. It required the school accountant to accept the students back on condition that the students signed a commitment agreement indicating when they expected date to pay the full amount. This is confirmatory to Khan, Mayes and International Monetary Fund (2012) description of accounting practices ensures reporting regardless of the actual occurrence of payment or receipting of cash. This system was further echoed by one of the deputy-headteacher Gold:

“...accounts office is allowed to accept school fees paid in form of post-dated cheques, bank drafts and mobile money electronic payments-head-teacher authorises all students that report without full payment”.

Another senior accountant Brown deferred by saying:

“...requisition forms... ...there numbered to avoid duplication or repetition of recordings in the voucher. ...preformed invoices are used to writing requisitions... ...limits altering of prices."

Furthermore, accrual preventive financial control measures use technological software such as tally accounting software to facilitate data storage and reporting. This was further explained how it influenced the mobilising of school revenue. accountant Yellow had this to say:

"...Say, using of accrual system, which is obviously with the help of tally, enables us to extract students' balances, ... these monitors who failed to meet the commitment date signed ... which is effective in a term of timely reporting".

Brown, Gold, Blue, Black, Yellow, Purple, Pink and Silver reported evidence confirmed that the used preventive financial controls through segregation guidelines although, the use of accrual-based control resulted into positive influence on the schools' revenue collecting. Reporting post-dated cheques, receipting bank drafts, requisition and mobile electronic payments using electronic and 
manual methods in Tally accounting software, encouraged timely reporting of financial information. These measures are confirmatory to (PWC, 2013; Tarantino, 2010) argument that it minimises the risks in mobilization of revenue, ensuring as an accountability technique of raising and spending revenue when carrying out the process.

Headteacher Lemon echoed how this influenced the mobilization, saying;

"...deposited in the bank no cash is acceptable at the school as school fees. ...receipts of the school bank slip copies are entered into the accrual-based system ...minimises on the fraud issues that might arise ...from unfaithful or untrustworthy staff and fake notes of money brought by parents..."

This view suggests these accrual-based systems were significant in minimising fraud and the use of forged bank notes. Alternatively, auditor Maroon indicated that this system ensured the analysis of actual balances and physical cash by saying;

"An accrual-based system is used where recognition of revenue and expenditure is computed before any cash movement which is an acceptable accounting principle which conforms well financial reporting standards. ...vital in informing the enrolment size as a key investment performance factor... the system is more effective on cash at hand transactions...”

Maroon opposed the previous respondents with negative influence of accrual-based accounting control process in segregated duties by indicating that accrual system seems to have created delayed payments or reluctance since some of the parents fail to honour their commitment. Headteacher Lime agreed by saying:

“.... it's unfortunate we sometimes find the guidelines unsupportive, especially that which introduced the accrual system. Parent's commitments are untrustworthy, they are reluctant because their child is in school, and they forget to honour their word. So, we lose good investment opportunity...”

Board member Chocolate echoes “...we miss out a lot especially with delayed accumulation of funds due to several debtors balance reported in meetings..." Supplementing these respondents Auditor Maroon- “...brilliant students from low-income backgrounds, fail to pay in time, but we are result oriented ...so, some get accepted back before full payment, even though from potential families exploit this. In the end ... accumulating debtors in the system ... more creditors, static educational projects etc.”.

Another auditor Red continued to note that the accrual-based system encouraged writing off failed payments balances as bad debts due to relaxation of parents in making payments in a given time period. He adds that its influence is suppliers growing impatient thus cutting off supplies as delayed making their payments. Those who continued supplying on credit would instead provide the 
schools with low-quality inputs. Therefore, the accrual system forced the schools not to follow the planned budget in times due to insufficient cash. A similar criticism was made by one of the accountants who added that the guideline led to unrealistic estimations of the revenue needed to finance the budgeted expenditure. Planned revenue was determined based on enrolment size, but the estimate ignored the fact that with the accrual system, some students tend not to pay. A proposition emerging from this, was to use realistic revenue estimations by including a default rate to cater for the minority who fail to pay as predicted basing on previous data. These results support studies by (Klamm \& Watson, 2009; Mcnally, 2013; Rubino \& Vitolla, 2014), that ineffective preventive control as accrual-based system increases the risks in organisation. Consequently, the accrual system was perceived as an inefficient practice in schools to realise their revenue as planned. Therefore, the validity of the findings was discussed in the section below.

\section{Discussion and Conclusion}

There is empirical evidence that there are implemented preventive controls within the financial guidelines, segregated duties, and IT operations used in Ugandan private school revenue mobilization; however, these controls were partially valid in influencing the revenue mobilization in a positive or negative manner in association with COSO control activities, to achieve the efficient, effective, reliable and compliant guidelines in mobilization of revenue. Drawing upon scholars' studies by (Burns et al., 2014; PWC, 2013), control activities in private schools in Uganda credited that the use of designed preventive control guidelines that are reliable, compliant, efficient and effective, discourages or encourages raising and spending desired revenue.

\subsection{Efficiency and Effectiveness}

Theoretically, Financial Reporting Council (2005) is credited in the study indicating that efficiency and effectiveness COSO control activities play an essential role in ensuring business success. Empirical evidence from the study credits Commonwealth Secretariat (2005) and Mpolokeng (2011) research, that Ugandan private internal stakeholders in school have designed financial committee meetings, consulting professional accountants, encouraging budgeting and planning which are significant COSO control guidelines in mobilizing desired revenue. The study further attributed to Burns et al. (2014) and PWC (2013) analysis that private schools outlined guidelines to segregate complex duties such as budgeting, auditing process, monitoring students' balances, analyzing expenditure and raising revenue, post-dates cheques practice and bank draft routine, encouraged efficiency in revenue mobilisation process. This therefore supported Oche (2009) and Tarantino (2010) studies that indicated this as streamlined and authentic accounting efficient and effective practices in internal preventive controls. Therefore, private schools designed effective and efficient 
COSO control activities within their preventive financial control guidelines to generate desired revenue which was effective and efficient. Further scrutiny is explained in the COSO preventive control reliability.

\subsection{Reliability}

Likewise, the school indicated that they were implemented reliable preventive guidelines that discouraged and encouraged mobilizing desired revenue. According to the findings, Financial Reporting Council (2005) the reliability factor within the preventive financial guidelines was not entirely valid in the private school revenue mobilization in Uganda. Empirical evidence suggests that to a great extent, the guidelines supported Commonwealth Secretariat (2005) and Mpolokeng (2011) where, private school limited financial risks such as avoiding reporting misleading reconciliation data, over budgeting, under budgeting, forged money from clients, and fraud during the financial reporting, this process encouraged mobilization of desired revenue. These controls support findings (seen in Aase, 2009; Commonwealth Secretariat, 2005; Gathii et al., 2014; Hopkin, 2018; Mpolokeng, 2011; Oche, 2009; PWC, 2013; Schandl \& Forster, 2019; Tarantino, 2010). On the contrary, the preventive guidelines were unreliable which adverse effect on the desired revenue realised in the schools. These included debts accumulations, delay or discouragement investment in school projects during the use of accrual-based system. This credits scholars (Aase, 2009; Mpolokeng, 2011; Oche, 2009) arguements that supported that designing poor guidelines in schools and business, discouraged positivity intended outcomes, in this study was desired mobilized revenue. Specifically, Gathii et al. (2014) reported that it is better for schools to design less risky preventive control guidelines to unburden the mobilization of revenue in the schools to avoid mismanagement of funds, which these schools failed through using inappropriate accrual-based system time management collecting of funds. This further sustained Schandl and Forster (2019) argument that schools just comply with the schools' set financial guidelines in place, rather than innovating better accounting principles that boost the realisation of the desired revenue. In conclusion, reliance of preventive financial control guidelines used in the schools is not well structured to effect desired revenue to boost investment, thus still a challenge. Further analysis was explained using COSO preventive control compliance.

\subsection{Compliance}

Empirical evidence further indicates that compliance in preventive control to mobilise revenue is still a challenge in Ugandan private schools. As in Financial Reporting Council (2005), the compliance guidelines were to a great extent inefficient in operations within the technology process, rather complied within segregated duties' guidelines. These schools ensured that their guidelines of mobilization were complied with when depositing all payments in a bank, use complying documents as bank slip and different issuing offices when executing the ac- 
counting tasks. These forms of control tasks credit Tarantino (2010) as preventive controls enabled school to realise revenue. Additionally, compliance was ensured in process of duties allocated to the accountants such as bank reconciliation, recording vouchers, recording invoices, writing requisitions, receipting admission, receipting purchased school items and receipting admission of new entrants. These practices credit scholars (Aase, 2009; Commonwealth Secretariat; 2005; Gathii et al., 2014; Mpolokeng, 2011; Oche, 2009; PWC, 2013; Schandl \& Forster, 2019; Tarantino, 2010) inducing better outcomes such as realisation of desired revenue to boost school projects in private schools in Uganda. However, technological preventive control guidelines designed influenced the schools negatively. Schools were compliant in using both manual and electronic bookkeeping, this included financial databank, authentic bank slip stamps, computer reporting, using tally software, mobile money electronic payments. Yet, the manual method associated to accrual-based system caused debtors and creditors figures accumulating. This showed inefficiency in compliant preventive guidelines designed in schools. This credited Rubino and Vitolla (2014) analysis which indicated that poor IT technology guidelines and firewalls designed to bookkeep in accounting as in these schools largely had a significant role in hindering the realisation of desired revenue. In conclusion, although private schools in Uganda complied with their own financial control guideline, it generates undesired revenue which suggests the bankruptcy incurred by some investors in school businesses. Therefore, the preventive financial control guidelines are not entirely effective, efficient, reliable and complied to within private schools' revenue mobilization to support the school planned projects, thus leading to some schools running bankrupt which this study has evidenced.

\section{Recommendations and Indicators of Further Research}

In the study, it shows that some of the schools had manually recorded data, the school is recommended to reform the accrual-based system to increase the rate at which financial activities are performed using alternatives such as implementing electronic reporting improved accounting software. The school is recommended to clearly sensitise parents and students on matters regarding school financial benefits of timely payment through clear explanation of the advantages and disadvantages of defaulting the financial regulations from late payments. Further implications of the study show evidence that the schools use computerised system which led to continuous errors reflected on the students' school fees balance. The school is advices to enforce both an alternative backup system and upgrading the software such as manual entering of data. The schools are encouraged to recruit more auditors to minimise on the job ambiguity rather than relying on internal auditors.

There are limitations that were identified in the study, for instance, the method used to obtain results generalised findings depending on four private secondary schools in Uganda context which represented all private schools in 
the nation, however, this narrows the significance of the research. Therefore, further research is recommended to use a quantitative method which increases the sample size to strengthen the validity of the results. Additionally, the findings were only limited to private secondary schools, excluding private primary schools, tertiary institutions and high institutions, thus narrowing the significance of the study. Therefore, further research could be expanded into private education with a larger context. Furthermore, further research needs to be conducted using mixed method approach research to show whether the findings are similar.

\section{Conflicts of Interest}

The authors declare no conflicts of interest regarding the publication of this paper.

\section{References}

Aase, B. (2009). Measuring Charter School Financial Health (pp. 1-8). ERIC. https://files.eric.ed.gov/fulltext/ED539290.pdf

Alhojailan, M. I. (2012). Thematic Analysis: A Critical Review of Its Process and Evaluation. West East Journal of Social Sciences, 1, 39-47.

Bakalikwira, L., Bakalikwira, J., Kaawaase, T. K., Musimenta, D., \& Mukyala, V. (2017). Accountability in the Public Health Care Systems: A Developing Economy Perspective. Cogent Business \& Management, 4, Article ID: 1334995.

https://doi.org/10.1080/23311975.2017.1334995

Bauer, T. D., Bucaro, A. C., \& Estep, C. (2019). The Unintended Consequences of Material Weakness Reporting on Auditors' Acceptance of Aggressive Client Reporting. The Accounting Review. https://doi.org/10.2139/ssrn.3247092

Baxter, P., \& Jack, S. (2010). Qualitative Case Study Methodology: Study Design and Implementation for Novice Researchers. The Qualitative Report, 13, 544-559. http://www.nova.edu/ssss/QR/QR13-4/baxter.pdf

Becker, M. (2015). The Five Most Important Factors for Investment Success. The Simple Dollar; TheSimpleDollar.com.

https://www.thesimpledollar.com/investing/blog/five-most-important-factors-for-inves tment-success

Bhatta, T. P. (2018). Case Study Research, Philosophical Position and Theory Building: A Methodological Discussion. Dhaulagiri Journal of Sociology and Anthropology, 12, 72-79. https://doi.org/10.3126/dsaj.v12i0.22182

Burns, J., Deloitte, L. L. P., Herrygers, S., \& Deloitte \& Touche LLP. (2014). Heads Up-Challenges and Leading Practices Related to Implementing COSO's "Internal Control-Integrated Framework". Www.Iasplus.Com.

https://www.iasplus.com/en/publications/us/heads-up/2014/coso

Clandinin, D. J., Pushor, D., \& Orr, A. M. (2007). Navigating Sites for Narrative Inquiry. Journal of Teacher Education, 58, 21-35. https://doi.org/10.1177/0022487106296218

Clarke, V., \& Braun, V. (2016). Thematic Analysis. The Journal of Positive Psychology, 12, 297-298. https://doi.org/10.1080/17439760.2016.1262613

Committee of Sponsoring Organizations of the Treadway Commission (COSO) (2004). 
Enterprise Risk Management-Integrated Framework.

https://www.coso.org/Documents/COSO-ERM-Executive-Summary.pdf

Commonwealth Secretariat (2005). Managing Finance and External Relations in South African Schools. In Managing Schools in South Africa (pp. 1-200). Paris: OECD Publishing. https://dx.doi.org/10.14217/9781848598362-en

Crawfurd, L. (2017). School Management and Public-Private Partnerships in Uganda. Journal of African Economies, 26, 539-560. https://doi.org/10.1093/jae/ejx021

Cuaresma, J. C., \& Raggl, A. (2016). The Dynamics of Returns to Education in Uganda: National and Subnational Trends. Development Policy Review, 34, 385-422.

https://ideas.repec.org/a/bla/devpol/v34y2016i3p385-422.html https://doi.org/10.1111/dpr.12155

Dam, G. T., \& Volman, M. (2001). The Leeway of Qualitative Educational Research: A Case Study. International Journal of Qualitative Studies in Education, 14, 757-769. https://doi.org/10.1080/09518390110078422

Financial Reporting Council (2005). Financial Reporting Council Internal Control Revised Guidance for Directors on the Combined Code (pp. 1-24). FRC.

https://www.frc.org.uk/getattachment/fe1ba51a-578d-4467-a00c-f287825aced9/Revised -Turnbull-Guidance-October-2005.pdf

Gathii, K. J., Nassiuma, D., B, O. M., \& Karanja, D. (2014). Relationship between Financial Resourcesâ $€^{\mathrm{TM}}$ Accountability and Value Delivery in Secondary Schools in Kenya: A Survey of Nakuru County. International Journal of Management Sciences, 3, 886-908. https://ideas.repec.org/a/rss/jnljms/v3i12p4.html

Gordon, O. O., \& Kalenzi, A. (2019). Internal Control and Quality Service Delivery in a Public Health Sector: A Case Study of a Local Government in Uganda. African Journal of Business Management, 13, 557-563. https://doi.org/10.5897/AJBM2019.8819

Graneheim, U., \& Lundman, B. (2004). Qualitative Content Analysis in Nursing Research: Concepts, Procedures and Measures to Achieve Trustworthiness. Nurse Education Today, 24, 105-112. https://doi.org/10.1016/j.nedt.2003.10.001

Hopkin, P. (2018). Fundamentals of Risk Management: Understanding, Evaluating and Implementing Effective Risk Management. London: Kogan Page Publishers. https://books.google.co.uk/books?hl=en\&lr=\&id=bzFiDwAAQBAJ\&oi=fnd\&pg=PP1\& $\underline{\mathrm{dq}}=16 . \% 09$ Hopkin

Jacob, W. J., Holsinger, D. B., \& Mugimu, C. B. (2008). TCRecord: Article. Www.Tcrecord.Org; Teachers College Record.

https://www.tcrecord.org/content.asp? contentid $=14626$

Janvrin, D. J., Payne, E. A., Byrnes, P., Schneider, G. P., \& Curtis, M. B. (2012). The Updated COSO Internal Control-Integrated Framework: Recommendations and Opportunities for Future Research. Journal of Information Systems, 26, 189-213. https://doi.org/10.2308/isys-50255

Kaplan, R. S., \& Mikes, A. (2014). Managing Risks: A New Framework. Harvard Business Review. https://hbr.org/2012/06/managing-risks-a-new-framework

Kendall, J. E., \& Kendall, K. E. (2012). Storytelling as a Qualitative Method for IS Research: Heralding the Heroic and Echoing the Mythic. Australasian Journal of Information Systems, 17, 161-187. https://doi.org/10.3127/ajis.v17i2.697

Khan, A., Mayes, S., \& International Monetary Fund (2012). Transition to Accrual Accounting. Washington DC: International Monetary Fund.

Klamm, B. K., \& Watson, M. W. (2009). SOX 404 Reported Internal Control Weaknesses: 
A Test of COSO Framework Components and Information Technology. Journal of Information Systems, 23, 1-23. https://doi.org/10.2308/jis.2009.23.2.1

Loeb, S., Bryk, A., \& Hanushek, E. (2008). Getting Down to Facts: School Finance and Governance in California. Education Finance and Policy, 3, 1-19.

https://doi.org/10.1162/edfp.2008.3.1.1

Löfsten, H. (1999). Management of Industrial Maintenance-Economic Evaluation of Maintenance Policies. International Journal of Operations \& Production Management, 19, 716-737. https://doi.org/10.1108/01443579910271683

McCauley-Smith, C., Williams, S. J., Gillon, A. C., \& Braganza, A. (2013). Making Sense of Leadership Development: Developing a Community of Education Leaders. Studies in Higher Education, 40, 311-328. https://doi.org/10.1080/03075079.2013.842209

Mcnally, J. (2013). The 2013 COSO Framework \& SOX Compliance One Approach to An Effective Transition (pp. 1-8).

https://www.coso.org/documents/COSO\%20McNallyTransition\%20Article-Final\%20C OSO\%20Version\%20Proof 5-31-13.pdf

Middendorf, C. H., \& Macan, T. H. (2002). Note-Taking in the Employment Interview: Effects on Recall and Judgments. Journal of Applied Psychology, 87, 293-303.

https://doi.org/10.1037/0021-9010.87.2.293

Mpolokeng, T. E. (2011). The Effectiveness of Financial Management in Schools in the Lejweleputswa Education District. Ir.Cut.Ac.Za. http://ir.cut.ac.za/handle/11462/139

Nankumba, L. (2017). School Yearly Financial Reports [Face-to-Face to Liz Nantunda].

Nantunda, L., \& Ddungu, L. (2018). Does Detective Financial Control Influence Enrolment as a Performance Indicator of Private Investment in Secondary Education. Ugandan Internal Stakeholders' Qualitative Perspective. Public Policy and Administration Research, 8, 43-50.

https://www.iiste.org/Journals/index.php/PPAR/article/view/41537

Oche, D. (2009). Financial Management Practices of Secondary School Principals in Benue State (pp. 1-87). University of Nigeria.

http://www.unn.edu.ng/publications/files/images/project\%20work\%20oche\%20dean $\%$ 20(final\%20printED.pdf

Păunescu, M. (2020). COSO Model for Internal Control (II). CECCAR Business Review, 1, 40-46. https://doi.org/10.37945/cbr.2020.02.05

Professional Accountants in Business (PAIB) (2006). Internal Controls-A Review of Current Developments (pp. 1-19). New York: The International Federation of Accountants (IFAC).

http://www.ifac.org/system/files/publications/files/internal-controls-a-revie.pdf

PWC (2013). Committee of Sponsoring Organizations of the Treadway Commission Internal Control-Integrated Framework Executive Summary (pp. 1-20).

https://www.coso.org/Documents/990025P-Executive-Summary-final-may20.pdf

Rea, T. (2008). Informal Learning: A New Model for Making Sense of Experience. Journal of Adventure Education \& Outdoor Learning, 8, 160-162. https://doi.org/10.1080/14729670802601774

Rezaee, Z. (1995). What the COSO Report Means for Internal Auditors. Managerial Auditing Journal, 10, 5-9. https://doi.org/10.1108/02686909510088350

Rubino, M., \& Vitolla, F. (2014). Internal Control over Financial Reporting: Opportunities Using the COBIT Framework. Managerial Auditing Journal, 29, 736-771.

https://doi.org/10.1108/MAJ-03-2014-1016 
Schandl, A., \& Foster, P. L. (2019). Internal Control-Integrated Framework: An Implementation Guide for the Healthcare Provider Industry (pp. 1-28).

https://www.coso.org/Documents/COSO-CROWE-COSO-Internal-Control-Integrated -Framework.pdf

Ssekiziyivu, J. (2013). Challenges/Dilemmas of Private Secondary School Management and Leadership in Uganda (A Case of Selected Schools in Mukono District) (pp. 1-129). NLA Brage.

https://nla.brage.unit.no/nla-xmlui/bitstream/handle/11250/172031/John\%20Ssali\%20 oct\%2009.pdf? sequence $=1$ \&isAllowed $=y$

Tarantino, A. (2010). Essentials of Risk Management in Finance. Hoboken, NJ: John Wiley \& Sons. https://doi.org/10.1002/9781118387016

https://books.google.co.uk/books?hl=en\&lr=\&id=zo4K-yPeiC4C\&oi=fnd\&pg=PT15\&d $\mathrm{q}=$ define+preventive+internal+control1.\%09+2.\%09Tarantino

Tumwebaze, Z., Mukyala, V., Ssekiziyivu, B., Tirisa, C. B., \& Tumwebonire, A. (2018). Corporate Governance, Internal Audit Function and Accountability in Statutory Corporations. Cogent Business \& Management, 5, Article ID: 1527054.

https://doi.org/10.1080/23311975.2018.1527054

Vinnari, E., \& Skærbæk, P. (2014). The Uncertainties of Risk Management. Accounting, Auditing \& Accountability Journal, 27, 489-526.

https://doi.org/10.1108/AAAJ-09-2012-1106 


\title{
Appendix
}

\author{
Interview guide: Accountant, Auditors, Headteachers and Deputy \\ headteachers. \\ Date \& Time
}

\begin{abstract}
Interview preambles. than 1 hour. This will be recorded digitally, and responses will be kept confidential. Any the specific preventive financial control questions.

\section{General introductory questions.}

- Could you mention your position in the school?

- Could you mention your responsibilities in the school?

- How long have you worked in the school?

- Could you mention your highest education level?

Financial mobilization guidelines used in the collection of revenue.
\end{abstract}

The interview is a follow up of the completed consent form presented earlier and will take not more information provided will be used in the study without any trace to you or the organisation. You don't have to discuss anything you don't want to. Likewise, you can end the interview without you giving a reason. This interview is simple. I will start by asking general questions about your position, responsibility, your work experience and highest qualification. Then I will commence on

- Using relevant example or examples, could you mention the financial implemented guidelines followed to mobilize funds needed to run the school?

- Could you describe how effective the guidelines mentioned in previous example affect the investment performance of the school?

- As an individual, could you describe how the financial guidelines applied to guide mobilization of funds influenced the investment activities of the school?

Financial regulations for authorization of financial spending in the school.

- Using an example or examples, could you explain the regulations that are followed when authorizing the spending of money on investments undertaken at the school?

- Using an example could you explain the effect of the regulations on the investments undertaken in the school?

- Could you describe challenges in the reported regulations and how best they can be improved or amended?

Segregation of duties in collection of the revenue.

- Could you mention any example or examples of duties carried out in the financial department?

- Could you briefly explain how the duties are divided among the staff in the department?

- How does segregation of financial duties affect realization of what is expected from the investments undertaken in the school?

- Could you mention any possible ways by which desired investment results can be improved through segregation of duties?

Financial reporting guidelines used in the schools when reporting realised revenue.

- Using example or examples, could you describe the financial reporting guidelines used in the school?

- Could you explain how the example mentioned impacts on investment performance of the school?

- How do you think the financial reporting guidelines of the school can be improved? Closing question.

- What is the general comment on financial controls used in the schools?

Ending Remarks

Thank you for taking part in this interview. 


\section{Interview guide: Board of governors and directors. Date \& Time}

\section{Interview preambles.}

The interview is a follow up of the completed consent form presented earlier and will take not more than 1 hour. This will be recorded digitally, and responses will be kept confidential. Any information provided will be used in the study without any trace to you or the organisation. You don't have to discuss anything you don't want to. Likewise, you can end the interview without you giving a reason. This interview is simple. I will start by asking general questions about your position, responsibility, your work experience and highest qualification. Then I will commence on the specific preventive financial control questions.

\section{General introductory questions.}

- Could you mention your position in the school?

- Could you mention your responsibilities in the school?

- How long have you worked in school?

- Could you mention your highest education level?

Financial mobilization guidelines used in the collection of revenue.

- As a board member, could you describe the criteria used to formulate the financial guidelines governing the school?

- With an example or examples, could you mention financial guidelines followed when taking investment decisions in the schools?

Financial regulations for authorization of financial spending in the school.

- Using relevant examples or examples, could you describe the standard regulations used when authorizing financial spending on proposed investments in the schools?

- How could the above standard regulations that you have used that are inefficient be improved?

\section{Segregation of duties in collection of the revenue.}

- Could you elaborate whether the administrators who authorize the spending of money the same as those spend the money?

- Could you elaborate whether the official who authorizes the spending of money is the same person who verifies how the money is spent?

Closing question.

- What is the general comment on financial controls used in the schools?

Ending Remarks

Thank you for taking part in this interview. 